\title{
ВИКОРИСТАННЯ КОМП'ЮТЕРНИХ ТЕХНОЛОГІЙ У СИСТЕМІ ПОЧАТКОВОЇ МУЗИЧНОЇ ОСВІТИ
}

\author{
Ткачук С. М. Використання комп'ютерних технологій у системі початкової \\ музичної освіти. \\ У статті розглядається проблема використання комп'ютерних технологій у \\ професійній діяльності вчителя музики в ході проведення уроків музичного \\ мистецтва у початкових класах. \\ Ключові слова: комп'ютер, інформаційно-комунікаційні технології, \\ мультимедійні програми, навчальні комп’ютерні програми.
}

Ткачук С. М. Использование компьютерных технологий в системе начального музыкального образования.

В статье рассматривается проблема использования компьютерных технологий в профессиональной деятельности учителя музыки в процессе проведения уроков музыкального искусства в начальных классах.

Ключевые слова: компьютер, информационно-коммуникационные технологии, мультимедийные программы, обучающие компьютерные программы.

Tkachuk S. M Using computer technology in elementary music education.

The problem of the use of computer technology in the professional work of the teacher of music in the process of musical art lessons in primary school.

Key words: computer, information and communication technologies, multimedia programs, educational computer programs.

3 кожним днем інформаційно-комунікаційні технології (IКТ) все глибше є невід'ємним складником навчально-виховного процесу. Ще недавно інформаційними технологіями опікувалися тільки вчителі інформатики, нині ж це питання $є$ актуальним для кожного педагогічного працівника. Настав той час, коли ІКТ охоплюють різні галузі суспільного життя i їх можна застосувати під час викладання всіх навчальних дисциплін.

У науковій літературі висвітлено різноаспектні проблеми взаємодії людини 3 комп'ютером на рівні «нової свідомості», «нового мислення», «нових партнерських стосунків» (А. Берг, В. Винокуров, К. Зуєв, М. Сенченко, Ф. Рибаков, Е. Семенюк, Г. Смолян, А. Урсул); методології і теорії комп'ютеризації освіти (Б. Гершунський, О. Довгяло, М. Жалдак, Ю. Машбіц, Н. Морзе, О. Полат, О. Тихомиров); реалізації специфічних функцій комп'ютера у процесі навчання із застосуванням програмних педагогічних засобів (О. Гончаров, Ю. Кузнецов, Є. Маргуліс, І. Мархель, В. Монахов, Й. Ривкінд, Є. Рябчинська); обгрунтування психолого-педагогічних засад організації навчально-виховного процесу 3 використанням інформаційних технологій (Т. Гергей, М. Горський, В Ляудіс, Н. Тализіна, С. Юдін).

Meта статmi - проаналізувати доцільність і актуальність використання IКТ у процесі проведення уроків музичного мистецтва в початкових класах загальноосвітньої школи.

Державний стандарт початкової загальної освіти головною метою дисциплін художньо-естетичного циклу визначає розвиток особистісно-оцінного ставлення до 
мистецтва, здатності до сприймання, розуміння і творення художніх образів, потреби в художньо-творчій самореалізації та духовному самовираженні.

Виховання музикою має найточніше, найдоцільніше спрямування на розвиток духовного світу кожного школяра, пов'язується 3 його загальним розвитком, здійснюється в контексті становлення цілісної особистості.

Завдання вчителя - розвинути чутливість учнів до музики, ввести їх до світу добра й краси, допомогти відкрити в музиці животворне джерело людських почуттів і переживань, виховати здатність до активної різнобічної діяльності, сформувати ціннісно-орієнтаційне ставлення до музичного мистецтва, сприяти розвитку художньо-творчих здібностей дітей [4].

Успішному розв'язанню цих завдань та досягненню мети музичного виховання - формуванню у школярів музичної культури - сприятиме використання комп'ютера на уроках музичного мистецтва.

Як свідчить практика, уроки музики в комп'ютерних класах надають змогу одночасно працювати 3 персональним комп'ютером та розкривати творчі здібності школяра у процесі опанування сукупністю спеціальних знань і умінь, а також залучати їх до цілеспрямованої музичної діяльності: добір знайомої мелодії і гармонічного супроводу, складання власної мелодії, , організація акомпанементу у простих фактурних формах, оволодіння нотацією й основами музичної грамоти.

У роботі із першокласниками доцільно використовувати інтерактивну дошку. Електронні інтерактивні дошки - ефективний спосіб упровадження електронного змісту й мультимедійних матеріалів у масове середовище навчання. Назвемо види освітньої діяльності, що доступні під час використання електронної інтерактивної дошки:

- створення за допомогою шаблонів і зображень власних завдань для занять;

- демонстрація й нанесення нотаток поверх тексту, зображень, відео тощо;

- використання вбудованого у програмне забезпечення інтерактивної дошки презентаційного інструментарію для збагачення дидактичного матеріалу;

- демонстрація презентацій, створених учнями.

Задля демонстрації репродукцій, фотографій і схем можна приготувати слайди (наприклад, у програмі PowerPoint), у яких використовуються різні анімаційні ефекти. Матеріал супроводжуватиметься пояснювальним текстом, музикою, голосом диктора. Виокремлені ефекти створюють уявлення про деталі і символіку. На цих уроках можна використовувати безліч програм як для операційної системи Windows, так і для MS-DOC. Усі вони переважно дозволяють:

- створювати мелодію, наносити нотні знаки на віртуальний нотний стан;

- записувати мелодію, «натискаючи» клавіші на віртуальній клавіатурі;

- відтворювати створену мелодію (голосом, за допомогою звучання фортепіано, органа й інших музичних інструментів);

- корегувати, зберігати на диску, завантажувати мелодію.

За допомогою цих програм можна проводити музичні диктанти, розв'язувати задачі пошуку помилок у записі мелодій і тощо. Робота може бути організована так: перша половина класу працює з музичними фрагментами за комп'ютерами, друга 3 тестами на папері, потім групи міняються місцями. Тести на паперових картках складаються за допомогою, наприклад, програми Hyper Studio, потім роздруковуються [2].

Для початкової школи слід використовувати й інші можливості музичних редакторів, насамперед це прослуховування різних звукових записів (мелодії, 
казки, концерти, уривки з класичних музичних творів тощо). Комп'ютер можна використати і під час вивчення типів музичних інструментів.

За допомогою демонстрації різноманітних мультимедійних програм можна довідатися про історію створення, зовнішній вигляд обраного інструмента. Цю відео- й аудіоінформацію можна подавати на великому екрані через проектор або працювати з нею індивідуально (з використанням навушників). Саме ці можливості відповідають запитам програми початкової школи.

Переваги, що надає використання мультимедійних програм на уроках музики:

- кожен учень має доступ до клавіатури «фортепіано», «гітари» тощо;

- можливість озвучити записану мелодію спонукає учнів до творчого процесу створення мелодії;

- учень може «побачити» i «почути» будь-який відомий музичний інструмент;

- учитель має змогу швидко й об'єктивно контролювати та оцінювати знання учнів за допомогою комп'ютера.

Робота 3 навчальними комп'ютерними програмами на уроках музичного мистецтва відкриває перед учнями можливості експериментування з електронними звуками, а вибір медіазасобів для уроку, на якому застосовуються КНП, є питанням педагогічної й дидактичної стратегії, особистої компетенції та інтересу до засобів, якими користуватимуться і учитель, і учні.

Комп'ютер у школі нині- це безальтернативний засіб підготовки найцікавішого матеріалу до уроків музичного мистецтва. Маючи під рукою тисячі необхідних файлів, які зібрано за тематичними каталогами, учитель надає учням у кілька разів більше потрібної якісної інформації, яка закріплюється протягом уроку (учням не залишається навіть домашнього завдання). Отже, за допомогою комп'ютера вчитель розв'язує декілька важливих завдань - систематизація матеріалу для підготовки уроків та повнота його опрацювання на уроці.

Перевагою комп'ютерних навчальних програм також $є$ зацікавленість учнів матеріалом, незалежно від типу сприйняття, оскільки в роботі одночасно беруть участь зорові, слухові органи, що підсилюється позитивним емоційним станом учнів.

3 огляду на сказане, можна виокремити мету використання комп'ютерних ресурсів у системі початкової музичної освіти:

- розвиток мотиваційної сфери: формування пізнавальних інтересів до навчання, розширення способів пізнання довкілля;

- розвиток інтелекту учнів та активізація процесів мислення, пам'яті, уваги;

- художньо-творчий розвиток особистості учня;

- формування в молодших школярів системи музичних знань, умінь, навичок;

- технічне та технологічне оновлення процесу організації різних видів музичної діяльності учнів;

- забезпечення ефективного педагогічного керівництва у процесі комунікативної взаємодії вчитель-учень-комп'ютер-музика та можливості застосування інтерактивних форм роботи на уроці.

Комп'ютерні навчально-розвивальні програми володіють неабиякими навчально-виховними резервами, що забезпечують: 
- отримання дітьми на уроці музичного мистецтва цікавої, доступної, яскравої музично-теоретичної інформації, якісного наочно-слухового аудіоматеріалу;

- можливість урізноманітнення спектра музично-творчих завдань;

- реалізацію індивідуального, диференційованого підходу до кожного учня початкової школи;

- розширення діапазону колективних, групових форм музичної роботи 3 використанням інтерактивних методів навчання школярів.

Визначальним моментом у використанні можливостей комп'ютера на уроках музичного мистецтва має бути наявність у початковій школі відповідної матеріально-технічної бази, тобто комп'ютерів і відповідних навчальних музичних програм, що забезпечить одночасний доступ багатьох школярів (цілого класу) до інформаційних ресурсів, тобто архівів та файлів цифрового матеріалу. Обов'язковими у шкільному цифровому архіві повинні бути наявні файли:

1. Великі фонотеки цифрової музики українських, російських, зарубіжних композиторів, обробок класики в сучасній інтерпретації та багато іншого матеріалу. Нині наявні переведені на цифрові носії зразки національної музики. Державні архіви та інші організації, які причетні до зберігання старих грамзаписів, розв'язують питання їх перезапису та розповсюдження. Комерційні ж структури, які тиражують інформацію на цифрових оптичних носіях, також реалізують програми реставрації грамплатівок.

2. Добірка портретів та біографій композиторів, виконавців, музикантів, художників.

3. Велика кількість просканованих зображень музичних інструментів.

4. Архів нотної бібліотеки.

5. Архів творів: лібрето до опер, віршів, тощо.

6. Фонограми до пісень.

7. Просканована і відредагована в цифровий вигляд методична література.

8. Переведені в цифровий вигляд фрагменти потрібних для уроків фільмів, мультфільмів, відеоінформація.

9. Записи найкращих вокальних творів у виконанні дітей, архів яких $з$ часом поповнюватиметься.

У підготовці архіву вчитель може Інтернетом, де існують спеціальні сайти («Музика в школі»), де можна знайти всю необхідну для уроку інформацію. Це також дасть можливість співпрацювати вчителям і музикантам, обмінюватися матеріалом для подальшого збільшення необхідної інформації і використання їі на уроках у школах. Нині спілкування і співпраця через Інтернет $є$ ефективним i результативним варіантом роботи вчителя [3].

Комп'ютерні технології навчання за дидактичними функціями: технологіям;

- збільшують і стимулюють інтерес учнів завдяки мультимедійним

- активізують розумову діяльність й ефективність засвоєння матеріалу завдяки інтерактивності;

- дозволяють моделювати й візуалізувати процеси, складні для демонстрації в реальності.

Щодо проблеми вивчення дидактичних функцій комп'ютера на уроках музичного мистецтва, можна зазначити, що у предметах мистецького циклу рівень 
комп'ютеризації значно нижчий, ніж у дисциплінах, що відображають зміст фундаментальних наук.

Але водночас $\epsilon$ низка оригінальних комп'ютерних програм, які можна використовувати на уроках музичного мистецтва. Саме за їх допомогою $\epsilon$ можливість формувати зміст комп'ютерних технологій на уроках музики. Зазначимо, що останні дозволяють розглядати комп'ютер як засіб навчання, допомагають реалізувати в навчальній діяльності методи програмованого та проблемного навчання.

Застосування комп'ютерних технологій на уроках музичного мистецтва відкриває нові можливості та перспективи розвитку творчої особистості учня. Завдяки цим технологіям виникають принципово нові підходи до підвищення інформативності окремих базових знань, що формуються на основі єдності закономірностей абстрактного та конкретно-предметного мислення. Зміст знань, якими оволодіває учень на уроках, пов'язаний зі специфікою термінології та словниковим запасом. Водночас зазначимо, що під поняттям «абстрактне мислення» ми розуміємо спосіб діяльності щодо формування у свідомості учнів понять та уявлень, які відрізняються інтегральними якостями на основі синтезу інтелектуальних уявлень з образами музичних фантазій.

Конкретно-предметне мислення передбачає спосіб діяльності, що забезпечує оперування художніми засобами виразності, які притаманні особливостям музичної мови, але ні абстрактне, ні конкретно-предметне мислення не існують у чистому вигляді.

Задля реалізації функцій щодо використання комп'ютерних технологій сформувався такий спектр дидактичних умов:

- забезпечується взаємозаміна понять з урахуванням синтезу мови музики та екрана комп'ютера;

- екран комп'ютера орієнтує учнів на новий віртуальний світ, що поєднує інформацію 3 лінійними та нелінійними рядками. У першому випадку передбачається встановлення логічних зв'язків між окремими явищами, другому учні орієнтуються на використання прийомів домислювання, дофантазування, що забезпечує перехід від дискретних фрагментів до цілісного сприйняття інформації;

- забезпечується внутрішня єдність змісту (принцип поєднання компонентів інтелектуальних $з$ емоційно-образними);

- оптимальне співвідношення конкретно-предметних дій i теоретичних знань;

- системність і послідовність навчання, які досягаються шляхом виконання завдань (від простого до складного, від одиничного до загального і навпаки, від відомого до невідомого);

- ураховуються уявлення про пізнавальні процеси.

Комп'ютерні музичні навчально-розвивальні програми можуть застосовуватися вчителем під час організації будь-якого етапу уроку: сприймання музики, вокально-хорової діяльності, інструментального музикування, музичнопластичної інтерпретації образного змісту творів, під час вивчення основ музичної грамоти, засобів музичної виразності, історії музичного мистецтва тощо. Мультимедійна технологія музичного навчання передбачає використання таких програм: «Музичний клас», «Шарманщик», «Первинні музичні жанри. Танець», «Чарівна музична сходинка», «Музична скринька», «A Musical Tutorial», «Making 
music», «Cakewalk Рго Audio», «Visual Аггаngeг», серія «Енциклопедія музичних інструментів», серія «Класична музика» та інші [1].

Отже, комп'ютер на уроці музики стимулює творчий пошук, розвиває уяву, сприяє творчому мисленню учнів. Використання інформаційних технологій дозволяє залучити учнів до створення творчих робіт, пошукової роботи під час вивчення народної творчості, української музичної культури, творчості композиторів світу, оформлення результатів своїх досліджень у вигляді методу проектів за певними темами.

\section{Література}

1. Василенко Е. В. Шляхи застосування комп'ютерних технологій на уроках музичного мистецтва / Е. В. Василенко // Мистецтво в школі. - 2010. - № 1.- С. 3-5. 2. Клокар Н. I. Концепція діяльності наукової лабораторії інформаційних технологій навчання КОІПОПК // Організація діяльності наукових лабораторій інституту: наук.-метод. посібник / Н. І. Клотар, О. В. Чубачук, О. П. Вітюк / За ред. Н. І. Клокар, О. В. Чубарук. - Біла Церква, 2005. - С. 51-55. 3. Опанасюк О. П. Музична творчість школярів: проблеми та перспективи розвитку методики / О. П. Опанасюк // Мистецво в школі. - 2009. - № 10. - С. 2-7. 4. Пометун О. І. Сучасний урок. Інтерактивні технології навчання: наук.-метод. посібник / О. І. Пометун, Л. В. Пироженко; за ред. О. І. Пометун. - К. : А.С.К., 2004. - 192 с.

$$
\text { УДК : 373.5.016:911.3: [314.1] }
$$

Олег Топузов, Олександр Федій

\section{ПОНЯТТЯ «ТРИВАЛІСТЬ ЖИТТЯ» ЯК ДЕМОГРАФІЧНИЙ КОМПОНЕНТ ШКІЛЬНОЇ ГЕОГРАФІЧНОЇ ОСВІТИ}

Топузов О. М., Федій О. А. Поняття «тривалість життя населення» як демографічний компонент шкільної географічної освіти.

Демографічна характеристика населення - важлива складова шкільної географічної освіти. Поняття «тривалість життя» $є$ необхідним елементом багатьох демографічних процесів, які відбуваються у державі та світі загалом. У статті обгрунтовано поняття «тривалість життя» як одну з найважливіших категорій під час вивчення учнями економічної і соціальної географії у 9-му і 10-му класах.

Ключові слова: тривалість життя населення, якість життя населення, демографічна характеристика.

Топузов О. М., Федий А. А. Понятие «продолжительность жизни» как демографический компонент школьного географического образования.

Демографическая характеристика населения - важная составляющая школьного географического образования. Понятие «продолжительность жизни» является необходимым элементом многих демографических процессов, которые происходят в стране и мире в целом. В статье обосновано понятие «продолжительность жизни» как одна из важнейших категорий во время изучения экономической и социальной географии в 9-ом и 10-ом классах.

Ключевые слова: продолжительность жизни населения, качество жизни населения, демографическая характеристика.

Topuzov O. M., Fediy O. A. The concept of «life expectancy» as a demographic component of school geography education. 